\title{
Концептуальні підходи до формування критеріїв оцінювання ефективності системи внутрішнього контролю в Міністерстві оборони України
}

\author{
Станіслав Слободяник ${ }^{1}$ А; Павло Пархоменко 2 А; \\ Олександр Деменев ${ }^{3}$ в; Іван Ткач 4 А \\ А Національний університет оборони України імені Івана Черняховського, пр-кт Повітрофлотський, 28, г. Київ, 03049, Україна
}

Received: June 4, 2021 | Revised: June 15, 2021 | Accepted: June 30, 2021

DOI: $10.33445 / s d s .2021 .11 .3 .16$

\begin{abstract}
Анотація
В статті розглядаються основні причини уповільнення розвитку системи внутрішнього контролю в державному секторі України, яка виступає інструментом підвищення ефективності функціонування об'єкта контролю в цілому. Метою статті є розробка, на базі системного та процесного підходів, концептуальних підходів до формування критеріїв оцінювання ефективності системи внутрішнього контролю в довгостроковій перспективі та визначення найбільш адаптованого стандарту для даної цілі. В процесі досягнення мети дослідження використовувались наступні методи: аналіз, синтез, індукція, дедукція, системний підхід, аналогія.

Світова тенденція до підвищення прозорості функціонування державних установ реалізується шляхом впровадження системи внутрішнього контролю, як елемента системи управління установою. При цьому виникає необхідність в оцінюванні ефективності самої системи.

Функціонування належного внутрішнього контролю та внутрішнього аудиту $\epsilon$ обов'язковою умовою вступу нових держав-членів в ЄС. Проведений аналіз вітчизняної нормативно-правової бази в сфері функціонування системи внутрішнього контролю показав відсутність в Україні єдиної методики оцінювання її ефективності в державному секторі та нагальну необхідність в її створенні.
\end{abstract}

Ключові слова: внутрішній контроль, внутрішній аудит, ефективність, COSO, FERMA.

\section{Постановка проблеми}

Пришвидшення змін зовнішнього середовища, яке обумовлено розвитком інформаційних систем і технологічним розвитком суспільства, веде до необхідності пристосування суб'єктів господарювання до нових реалій та до факторів, які впливають на внутрішнє та зовнішнє середовище суб'єкта. Одним із основних інструментів забезпечення успішності ведення фінансовогосподарської діяльності (і не тільки) $\epsilon$ система внутрішнього контролю (далі - СВК), яка повинна не тільки відстежувати зазначені зміни, але i запроваджувати шляхи пристосування та підвищення ефективності діяльності організації в цілому. Тому виникає необхідність оцінювання ефективності СВК для вдосконалення ії діяльності. В рамках цього процесу використовується система внутрішнього аудиту самої СВК. Вона виступає об'єктивним оцінювачем та

\footnotetext{
1 * Corresponding author: к.е.н., с.н.с., провідний науковий співробітник науково-дослідної лабораторії проблем фінансового забезпечення, е-таі: 8s.8@ukr.net, ORCID: 0000-0001-5537-2723

2 к.е.н., старший викладач кафедри економіки та фінансового забезпечення, e-mail: p_parhomenko@ukr.net, ORCID: 0000-0002-1026-3723

${ }^{3}$ к.т.н., доцент, доцент кафедри економіки та фінансового забезпечення, e-mail: p_parhomenko@ukr.net

${ }^{4}$ д.е.н., професор, Начальник навчально-наукового центру оборонного менеджменту, e-mail: tkachivan9@gmail.com, ORCID: 0000-0001-55476303
} 


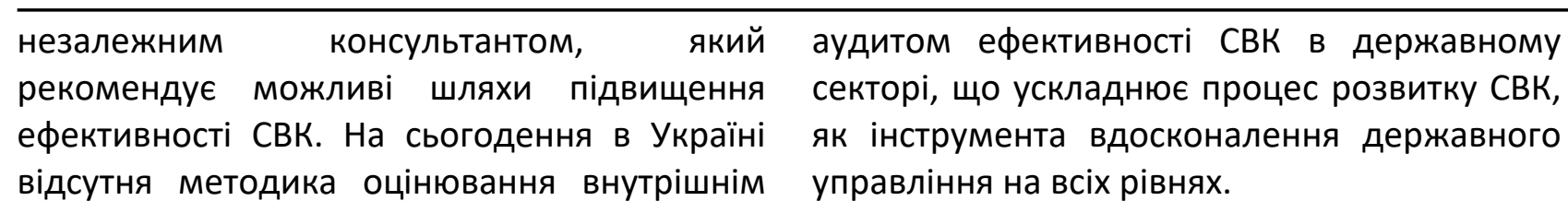

\section{Аналіз останніх досліджень та публікацій}

Питання ефективності СВК в своїх роботах розглядали: Л.Ю. Патраманська, С.В Бардаш, Р.О. Костирко, Н.Г. Виговська, В.О. Шевчук, В.Ф. Максімова, В.І. Горло, Т. Педді, А.Дж. Калдвел, Х. Болтон, А. Фолі, К. Хансел, Б. МакФарланд.

Дослідженням питань оцінювання ефективності СВК в своїх роботах займались: А. Тихомиров, І.В. Горло, І.Ш. Рахманкулов,
Р.О. Костирко, С.В. Бардаш, Т.С. Осадча, К. Безверхий, Д.С. Босалко, Т.Ю. Серебрякова, Т.М. Тарасова, О.А. Євтушевська, Д Ю. Філіпьєв, Л.Ю. Патраманська, В.А. Якімова, Г.В. Максимова, К.А. Каретников, С.Д. Даудов, О.Н. Ковальов, Н.І. Дорош, М.О. Фесай, С.А. Макаренко, А.А. Шаповалова, К. Дітмейер, П. Касаті, П. Моксі.

\section{Постановка завдання}

Проаналізувати діюче законодавство яке регламентує систему функціонування СВК в аспекті взаємодії із підрозділами внутрішнього аудиту (далі - ПВА) та дати оцінку інструментам впливу ПВА на підвищення ефективності СВК. Проаналізувати існуючі у світовій практиці стандарти створення та функціонування СВК, в аспекті їх придатності для державного сектору України та визначити найбільш прийнятну для ії̈ адаптації в національних реаліях.

Мета статті. На підставі проведеного аналізу, визначивши найбільш адаптовану до вітчизняного державного сектору модель CBK, запропонувати підходи до визначення критеріїв та показників ії ефективності у Міністерстві оборони України та Збройних Силах України.

\section{Виклад основного матеріалу}

В рамках даного дослідження доцільно розглядати Міністерство оборони України (далі - Міноборони) та Збройні Сили України як єдину систему, яка забезпечує воєнну безпеку держав (далі - організація). Функціонування CBK в державному секторі України та в Міноборони зокрема регламентується нормативно-правовими актами.

Розглянемо ступінь висвітлення питань CBK та внутрішнього аудиту в деяких нормативно-правових документах останніх років.

Статтею 26 Бюджетного кодексу України визначено поняття контролю та аудиту у бюджетних установах. Так в частині першій даної статті визначено що контроль забезпечує:

1) оцінку управління бюджетними коштами (включаючи проведення державного фінансового аудиту);

2) правильність ведення бухгалтерського обліку та достовірність фінансової i бюджетної звітності;

3) досягнення економії бюджетних коштів, їх цільового використання, ефективності і результативності в діяльності розпорядників бюджетних коштів шляхом прийняття обгрунтованих управлінських рішень;

4) проведення аналізу та оцінки стану фінансової і господарської діяльності розпорядників бюджетних коштів;

5) запобігання порушенням бюджетного законодавства та забезпечення інтересів держави у процесі управління об'єктами державної власності;

6) обгрунтованість планування надходжень і витрат бюджету [1]. 
У абзаці другому частини третьої статті 26 Бюджетного кодексу України наведено визначення внутрішнього контролю: "Внутрішнім контролем $€$ комплекс заходів, що застосовуються керівником для забезпечення дотримання законності та ефективності використання бюджетних коштів, досягнення результатів відповідно до встановленої мети, завдань, планів і вимог щодо діяльності розпорядника бюджетних коштів і підприємств, установ та організацій, що належать до сфери його управління" [1].

Пунктом 3 постанови Кабінету Міністрів України від 26 листопада 2014 року № 671 “Про затвердження Положення про Міністерство оборони України" визначені основні завдання Міноборони. СВК Міноборони призначено для контролю за його діяльністю, тобто виконання ним функцій та завдань. А через систему внутрішнього аудиту, вдосконалення СВК.

Абзац третій частини третьої статті 26 Бюджетного кодексу України наводить визначення внутрішнього аудиту: Внутрішнім аудитом $\epsilon$ діяльність, спрямована на вдосконалення системи управління, внутрішнього контролю, запобігання фактам незаконного, неефективного та нерезультативного використання бюджетних коштів, виникненню помилок чи інших недоліків у діяльності розпорядника бюджетних коштів і підприємств, установ та організацій, що належать до сфери його управління, та яка передбачає надання незалежних висновків і рекомендацій. Для здійснення внутрішнього аудиту розпорядник бюджетних коштів в особі керівника утворює самостійний структурний підрозділ внутрішнього аудиту, що $\epsilon$ підпорядкованим і підзвітним безпосередньо такому керівнику" [1].

СВК $€$ досить складною системою, що пов'язано із переплітанням процесів, які відбуваються в організації. Заходи самоконтролю та постійна зміна зовнішнього середовища (законодавство, суспільні вимоги, загрози, інше) потребують адаптації та постійного коригуючого втручання в СВК, що не завжди $є$ корисним та актуальним до нагальних потреб. Тому внутрішній аудит може здійснювати незалежне, об'єктивне оцінювання ефективності СВК та відповідності змінам внутрішнього і зовнішнього середовища. Таке оцінювання потребує застосування методик, критерії яких актуальні не тільки для організації в цілому, але і для специфічних функцій ії структурних підрозділів. Можна констатувати, що складність побудови методики буде зростати із складністю функцій організації.

Абзац четвертий частини третьої статті 26 Бюджетного кодексу України визначає: “Основні засади здійснення внутрішнього контролю і внутрішнього аудиту та порядок утворення підрозділів внутрішнього аудиту визначаються Кабінетом Міністрів України. Організаційно-методологічні засади здійснення внутрішнього контролю i внутрішнього аудиту визначаються Міністерством фінансів України, яке забезпечує формування та реалізацію державної політики у сфері державного внутрішнього фінансового контролю, у тому числі здійснює оцінювання функціонування систем внутрішнього контролю і внутрішнього аудиту" [1].

Слід зазначити, що незважаючи на регламентовану у Бюджетному кодексі України необхідність проведення внутрішнього аудиту у СВК, відповідні методики для державних установ відсутні та потребують створення.

Основні засади здійснення внутрішнього контролю визначені постановою Кабінету Міністрів України від 12 грудня 2018 року №1062 “Основні засади здійснення внутрішнього контролю розпорядниками бюджетних коштів", зокрема визначення внутрішнього середовища, управління ризиками, здійснення заходів контролю, здійснення інформаційного та комунікаційного обміну, здійснення моніторингу [2].

Згідно абзацу третього та четвертого, пункту 4 постанови Кабінету Міністрів України від 28 вересня 2011 р. № 1001 “Деякі питання здійснення внутрішнього аудиту та утворення підрозділів внутрішнього аудиту" (далі - 
Постанова №1001) визначені основні завдання ПВА, які полягають у наданні керівникові організації об'єктивних і незалежних висновків та рекомендацій щодо функціонування та удосконалення СВК [3]. Тобто при аналізі ефективності СВК, приділяється увага підвищенню ії об'єктивності та відповідності реальним умовам існування організації.

Дія Постанови № 1001 поширюється на міністерства, інші центральні органи виконавчої влади, зокрема на Міністерство оборони України. На виконання даної постанови, наказом Міністерства оборони України від 15 грудня 2020 року № 475 “Про організацію діяльності з внутрішнього аудиту в системі Міністерства оборони України" виконання завдань з внутрішнього аудиту покладено на Департамент внутрішнього аудиту Міністерства оборони України [4]. Наказом Міністерства оборони України від 5 червня 2019 року №280 “Про затвердження Положення про Департамент внутрішнього аудиту Міністерства оборони України" визначена основна мета діяльності ПВА, зокрема: “...здійснення ризик-орієнтованих та об'єктивних внутрішніх аудитів, надання рекомендацій, пропозицій і консультацій керівникам підконтрольних суб'єктів та обміну знаннями, що можуть сприяти підвищенню ефективності внутрішнього контролю і управління ризиками..." [5].

Пунктом 7 наказу Міністерства оборони України від 4 квітня 2019 року № 145 “Про затвердження Порядку організації в системі Міністерства оборони України внутрішнього контролю та управління ризиками" визначено, що на ПВА покладено оцінювання CBK [6], однак не зазначені заходи з аналізу їі ефективності, розробки рекомендацій по ії вдосконаленню і елементів консалтингу, як це визначено Стандартом 5 "Сутність діяльності з внутрішнього аудиту" у наказі Міністерства фінансів України від 04.10.2011 № 1247 “Про затвердження Стандартів внутрішнього аудиту". Зокрема, шляхом сприяння удосконаленню системи управління, СВК та управління ризиками через надання незалежних і об'єктивних висновків та рекомендацій [7].

Міністерством фінансів України в співпраці із Міністерством фінансів Нідерландів розроблено проект методичного посібника "Внутрішній аудит ефективності: методичні засади та практичні аспекти" [8], в якому визначені загальні принципи (в тому числі Концепція трьох “Е”) при формуванні критеріїв, що можуть застосовуватись під час проведення внутрішнього аудиту.

При аналізі нормативно правової бази визначена відсутність, законодавчо затверджених, методичних рекомендацій із оцінювання ефективності СВК в Міністерстві оборони України. Міністерством фінансів України не впроваджено загальних підходів або критеріїв, на які можна спиратись при розробці відповідної методики. Визначені законодавством обов'язки ПВА, вимагають від останніх розробляти методики оцінювання СВК в рамках функціоналу організації та впроваджувати власні критерії (показники) оцінювання ефективності СВК.

Оцінювання ефективності СВК буде більш результативним, в разі застосування в ній відповідних міжнародних стандартів, які регламентують методику створення та функціонування СВК та системи управління ризиками. Розглянемо основні міжнародні стандарти, проаналізуємо на предмет адаптованості до українських реалій та ролі внутрішнього аудиту в даному процесі.

Порівняльний аналіз міжнародних стандартів СВК та управління ризиками. Під час дослідження були проаналізовані стандарти та керівництва СВК та управління ризиками [9, 11, 12, 14, 15, 21-27], які діють провідних країнах. Для аналізу були обрані три стандарти, які широко використовуються у світовій практиці $[9,11,12]$. При їх аналізі застосовувались наступні критерії: визначення ризиків та управління ними; структура та принципи функціонування; роль внутрішнього аудиту; звітування та відповідальність.

1. Стандарт COSO (Committee of Sponsoring Organizations of the Treadway Commission). Розроблена в США та $\epsilon$ загально відомою в Україні та застосовується в більшості 
державних організацій. Коміся Тредвея володіє власною системою оцінювання ефективності СВК (Internal Control - Integrated Framework: Illustrative Tools for Assessing Effectiveness of a System of Internal Control), який застосовує тестування i перевірку ефективності елементів СВК [9]. Остання редакція стандарту була опублікована у 2017 році [9]. Даний стандарт є обов'язковим для застосування в публічних компаніях США. Один із небагатьох стандартів, який закріплено законодавчо. Закон Сарбейнса Окслі (Sarbanes - Oxley Act) від 2002 року зобов'язав щорічно оцінювати ефективність СВК та звітувати перед зовнішніми користувачами інформації про стан ефективності СВК [10].

1.1. Визначення та управління ризиками в стандарті COSO. Управління в організації здійснюється за принципом "розумної впевненості", що стосується досягнення цілей, при цьому ризики оцінюються з точки зору властивого (притаманного) i залишкового ризику, визначення стратегії та управління ефективністю інтегровані в організації і спрямовані на збереження вартості організації. Управління ризиками можливе, якщо ризик оцінений та піддається управлінню.

\section{2. Структура}

та

принципи

функціонування в стандарті COSO. Система в себе включає п'ять взаємопов'язаних елементів внутрішнього контролю: контрольне середовище; оцінювання ризику; заходи контролю; збір і аналіз інформації, передачу ї̈ за призначенням; моніторинг і виправлення помилок, взаємопов'язані із 8ма компонентами, які підкріплюються відповідними елементами. В світовій практиці графічне зображення даної моделі отримало назву “куб COSO".

1.3. Звітування та відповідальність в стандарті COSO. Звітування формується за критерієм максимальної прозорості для всіх зовнішніх користувачів (які можуть бути не пов'язаними особами 3 організацією). Відповідальність покладається на раду директорів та менеджерів всіх ланок.

1.4. Роль внутрішнього аудиту в стандарті
COSO. Він виступає останнім рубежем захисту організації, незалежним експертом, який визначає можливі прогалини в менеджменті організації, рекомендує можливі варіанти управління ризиками. Опрацьовує шляхи формування "додаткової цінності" організації.
1.5. Висновок
(стандарт
COSO).

Пріоритетом в стандарті COSO $€$ внутрішнє середовище організації та моніторинг, як виду контроля, що спирається на події, які завершились. Відповідальність ради директорів $\epsilon$ визначальною в організації.

2. Стандарт з управління ризиками FERMA [11] був розроблений спільно інститутом ризик-менеджменту в Великобританії (The Institute of Risk Management), Асоціацією ризик-менеджменту і страхування (The Association of Insurance and Risk Management) i Національним Форумом ризикменеджменту в Громадському Секторі (The National Forum for Risk Management in the Public Sector), прийнятий в 2002 році. $€$ прикладним інструментом і включає в себе відповідні рекомендації та форми документів. В його розробці застосовувалась термінологія ISO/IEC Guide 73: 2009 Risk Management, що сприяло його стрімкому визнанню та застосуванню в світі.

2.1. Визначення та управління ризиками в стандарті FERMA. Ризик розглядається як комбінація ймовірності i його настання. Ризики аналізуються системно за кожним видом діяльності, а ризик-менеджмент виступає центральною частиною стратегічного управління організацією. Зокрема, ризик визначається стандартом як “комбінація ймовірності події та ії наслідків".
2.2. Структура
та
принципи функціонування в стандарті FERMA. При управлінні ризиками застосовуються широко використовуються діаграми, які відображають ключові ризики: фінансові, стратегічні, операційні, загрози.

2.3. У Стандартах управління ризиками (FERMA) визначено, що роль внутрішнього аудиту може варіюватись від організації до організації, та на практиці до внутрішнього аудиту висуваються наступні вимоги:

“...приділяти увагу окремим ризикам, 
відповідно до загальної програми управління ризиками;

проводити аудит системи управління ризиками в організації в цілому;

здійснювати підтримку управління ризиками організації;

здійснювати підтримку процесу управління ризиками в організації й активно в ньому брати участь;

сприяти процесу ідентифікації й аналізу ризиків, а так само брати участь у процесі навчання персоналу в питаннях управління ризиками та системи внутрішнього контролю; сприяти в підготовці й презентації звітів для керівництва організації і зовнішніх користувачів інформації" [10].

На рис. 1 графічно зображено місце внутрішнього аудиту в системі управління ризиками організації.

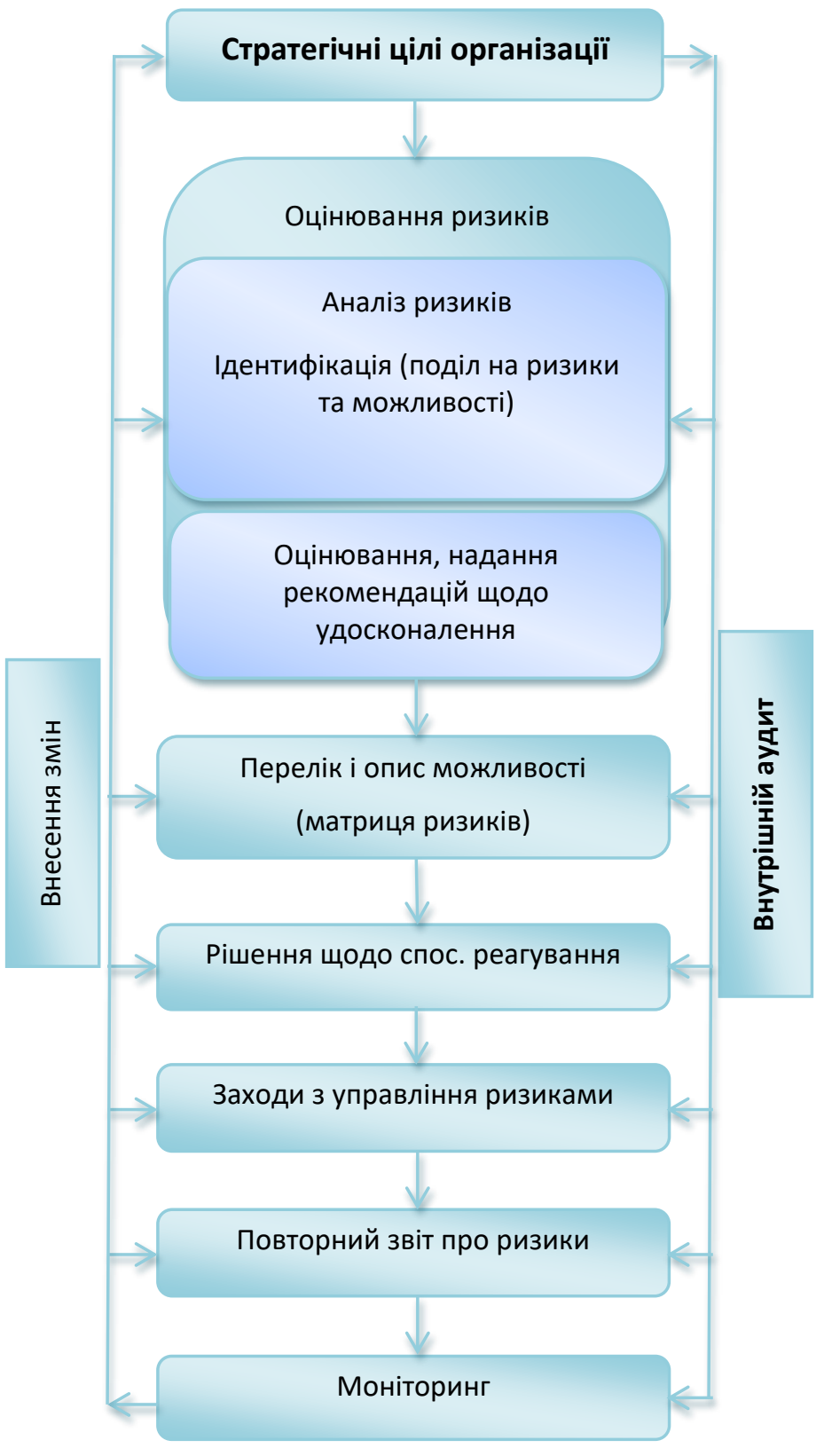

Рисунок 1 - Процес управління ризиками в організації (підхід FERMA) [10]

Як бачимо ПВА приймає активну участь у інструменти для підвищення ії ефективності. оцінці ефективності СВК та використовує свої 2.4. Звітування та відповідальність в 
стандарті FERMA. Формування, як внутрішнього так і зовнішнього звіту, у яких відображається інформація в тих розрізах, які $€$ цікавими для кінцевого споживача. Закріплені конкретні ролі за радою директорів, структурними одиницями, ризикменеджерами, ПВА та відповідальність за розробку і реалізацію системи управління ризиками.

2.5. Висновок (FERMA). Особливістю даного стандарту $\epsilon$ те, що ризик розглядається, як невизначеність і може впливати на організацію, як негативно так і позитивно, на відміну від COSO, де ризик розглядається виключно негативно. Містить конкретні методи і технології оцінювання позитивних, негативних ризиків, а також інструменти, що підходять для обох видів.

3. Міжнародний стандарт ISO 31000:2018 [12] може бути застосований протягом всього життєвого циклу організації, а також придатний для широкого спектру видів діяльності, включає стратегії і рішення, операції, процеси, функції, проекти, продукцію, послуги і активи. Процес управління ризиками включає прийняття найбільш оптимального рішення по відношенню до рівня ризику. Даний стандарт розроблений і адаптований під різні сфери діяльності. Більше уваги приділяється лідерству 3 боку топ-менеджменту i необхідності інтеграції ризик-менеджменту в бізнес процеси організації.

3.1. Визначення та управління ризиками в стандарті ISO 31000:2018. Встановлення контексту передбачає аналіз зовнішнього і внутрішнього середовища організації та встановлення контексту менеджменту ризиків, на які система управління ризиками може вплинути. Встановлення критеріїв ризиків, та визначення можливостей впливу на нього, при цьому ризики класифікуються за напрямками діяльності організації, визначаються фактори що вплинули на появу ризиків. Управління ризиками розглядається в розрізі підрозділів організації.
3.2. Структура
та
принципи

функціонування в стандарті ISO 31000:2018. Включає в себе набір принципів: лідерство керівництва; облік людських особливостей; інтеграція в процеси; ітеративний характер

3.3. Роль внутрішнього аудиту в стандарті ISO 31000:2018. Оскільки даний стандарт передбачає сертифікацію шляхом проведення зовнішнього аудиту функціонування системи, відповідно внутрішній аудит спрямований на ефективне ії функціонування, шляхом виявлення критичних та не критичних ризиків, пошук не виявлених і оптимізація способів ідентифікації загроз.

3.4. Звітування та відповідальність в стандарті ISO 31000:2018. Відповідальність закріплена за всіма рівнями управління. Високий рівень свобод користувачів системи через зменшення вимог до звітності та регламентації визначеної стандартом. Користувачі самі визначають методи і періодичність звітності.

3.5. Висновок (ISO 31000: 2018). Даний стандарт на відміну від FERMA, де пропонується комплексний підхід із певною періодичністю перевірок та звітності, ISO 31000: 2018 пропонує підхід із певним рівнем свободи до періодичності, але індивідуальний підхід до роботи з кожним конкретним ризиком. Як і в FERMA ризик може мати позитивні наслідки для організації.

Продовжуючи аналіз стандартів управління ризиками, звернемо увагу на дослідження [13], в якому визначається необхідність проводити оцінювати і фіксувати не тільки фактичні невідповідності, але i потенційні ризики при проведенні внутрішнього аудиту. А виявити потенційні невідповідності досить складно, якщо не застосовувати методологію оцінювання ризиків. Ризик-орієнтований аудит - один із напрямів розвитку внутрішнього аудиту, в рамках оцінювання ефективності СВК. Для цього керівники і внутрішні аудитори повинні знати і застосовувати методику оцінювання ризиків у своїй практичній діяльності. Методик різних багато, але практично всі засновані на оцінюванні ймовірності виникнення та тяжкості наслідків від можливої небажаної події (потенційної невідповідності). У стандарті ISO 9004: 2009 
говориться, що "проведення внутрішніх аудитів $\epsilon$ результативним способом виявлення проблем, ризиків і невідповідностей, а також моніторингу ходу робіт по усуненню раніше виявлених невідповідностей (з якими слід розбиратися на основі аналізу корінних причин, розробки і реалізації планів коригувальних і запобіжних дій)” [14]. Також: “Внутрішні аудити можуть бути спрямовані на виявлення передового досвіду, який може бути використаний в інших напрямках діяльності організації та на виявлення потенціалу поліпшень" [14].

B ISO/DIS 9001: 2014 визначено: “Цей стандарт робить ризик-орієнтоване мислення більш яскраво вираженим і включає його у вимоги, що відносяться до розробки, впровадження, забезпечення функціонування і постійного поліпшення системи менеджменту якості" [15]. Пропонований шлях проведення аудиту в разі застосування методики аналізу ризиків (в доповнення до оцінювання відповідності), власник процесу (керівник підрозділу) виявляє потенційні невідповідності, оцінює ризики (з складанням протоколу), планує і здійснює дії з метою зниження ризиків. Завдання аудитора при проведенні аудиту ефективності СВК - знайти відповіді на питання: чи враховані можливі потенційні невідповідності; в повному обсязі вказані можливі наслідки; чи правильно проведено оцінювання тяжкості наслідків; чи визначена причина потенційної невідповідності; чи правильно проведено оцінювання ймовірності виникнення потенційної невідповідності; чи заплановані заходи для зниження ризику (не прийнятні); чи достатньо заходів для зниження ризику; чи виконані заплановані заходи; чи результативно виконані заходи; чи врахована результативність заходів щодо зниження ризиків в стандартах, процедурах, інструкціях, інше.

у дослідженні [16], констатується, що світовий досвід дає можливість рекомендувати вітчизняним організаціям CBK за методикою COSO, яка сприяє актуалізації ризиків та акцентує увагу на зниженні рівня системних ризиків через процедури контролю, які адаптовані до кожного конкретного типу ризику, шляхом оцінювання системи внутрішнього контролю, який $є$ комплексним показником, що включає інтегральну оцінку якості кожного з елементів внутрішнього контролю у розрізі обов'язкових критеріїв, поданих у відповідній анкеті. На підставі аналізу розрахованих показників внутрішні аудитори оцінюють систему внутрішнього контролю шляхом привласнення рейтингу.

Виходячи із проведеного аналізу стандартів, які регламентують створення та функціонування СВК, найбільш прийнятною, на думку автора, є CBK за методикою COSO. До неї може бути адаптований підхід ризикорієнтованого внутрішнього аудиту та підходи визначені в стандартах [14, 15]. Також можуть використовуватись інструменти FERMA для підвищення ефективності СВК. Ведеться робота по адаптації стандартів COSO в умовах державного сектора, зокрема у Міністерстві оборони України впроваджені стандарти внутрішнього контролю, в яких використовуються компоненти моделі COSO [17]. ПВА зручніше орієнтуватись на стандарт COSO, оскільки при створенні Комісї Тредвея туди увійшли п'ять авторитетних асоціацій (до їх числа увійшов і Інститут внутрішніх аудиторів). Крім того для даного дослідження COSO має перевагу у вигляді власної системи оцінювання ефективності СВК (Internal Control - Integrated Framework: Illustrative Tools for Assessing Effectiveness of a System of Internal Control), що сприяє підвищенню якості аудиту ефективності процесів. Крім цього Інститутом внутрішнього аудиту (The Institute of Internal Auditors Research Foundation) розроблено у 2014 році комплексна модель оцінки (САМ) систем внутрішнього контролю для управління ризиками підприємств [18], ще одним альтернативним інструментом оцінювання ефективності СВК $€$ практичне керівництво з оцінювання та вдосконалення внутрішнього контролю в організаціях, розроблене Міжнародною федерацією бухгалтерів [19]. 
3 урахуванням того, що СВК є інтегрованою (комплексною) категорією, критеріальна оцінка рівня ефективності СВК повинна здійснюватися за допомогою системи показників, які у свою чергу, повинні характеризувати окремі складові СВК (окремі процедури, функції або групи процедур, функцій контролю).

Система показників повинна будуватися за ієрархічним рівневим принципом. Можливий варіант їі показаний на (рис.2).

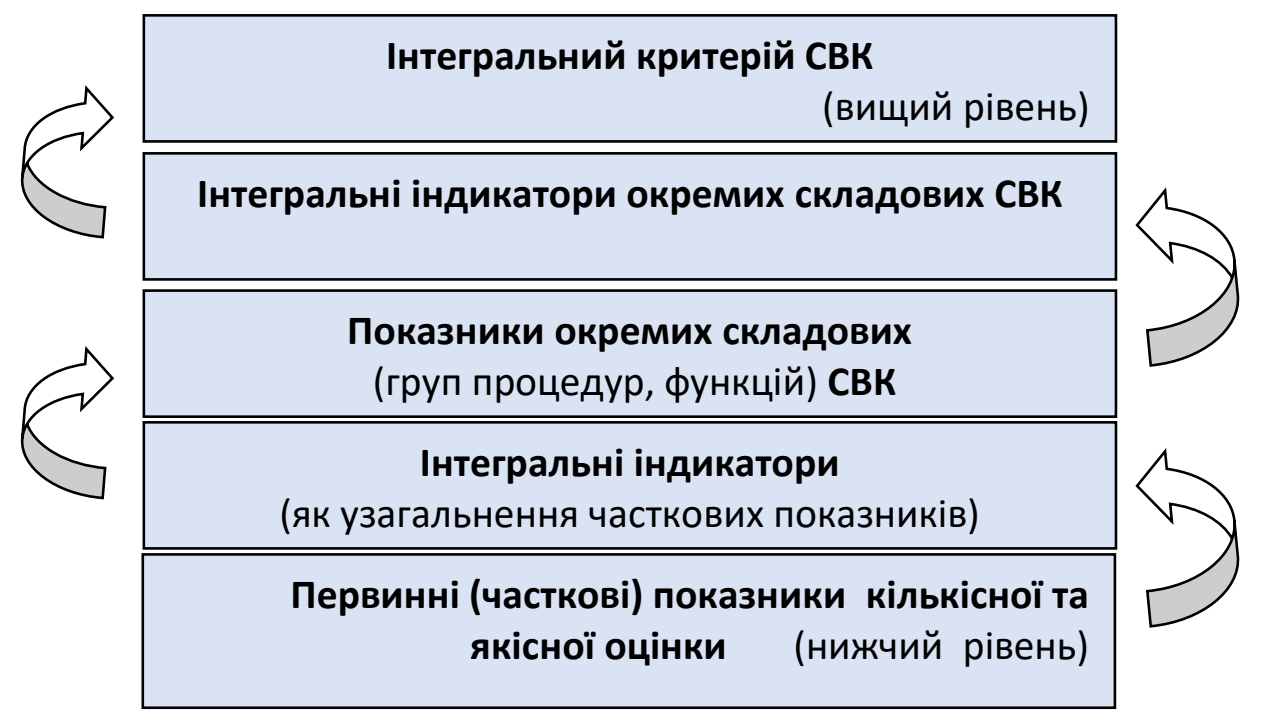

Рисунок 2 - Варіант ієрархічної системи показників, індикаторів, критеріїв оцінювання ефективності СВК

Показники нижчого рівня, індикатори, можуть бути утворені із традиційних для управлінської фінансово-господарської діяльності статистичних мікроекономічних показників установи (організації), соціальноекономічних показників або показників бойової підготовки, бойової готовності тощо, відбиваючих стан і динаміку діяльності установи за окремими складовими (напрямами) діяльності і в цілому.

Показники вищих рівнів можуть створюватися як самостійні, або як інтегральні з показників нижчих рівнів і відбивати стан справ у більш високих інстанціях управління (структурних підрозділах Міноборони).

Така побудова системи критеріїв дає можливість здійснювати оцінювання окремих складових СВК за певною ознакою і за певною глибиною (ступеню узагальнення ознак, що оцінюються і аналізуються), для подальшого відпрацювання "точкових" впливів (корегувань) на стан або на складник (групу складників СВК), або на СВК в цілому.
Крім методики обчислення часткових показників і індикаторів вищих рівнів СВК, повинна бути методика визначення порогових значень показників (індикаторів) для можливого аналізу окремих складових СВК і динаміки їх змін у позитивний, або негативний бік 3 метою формування відповідних коригуючих впливів.

Вищий рівень ієрархічної системи показників СВК установи може бути створений або єдиним інтегральним показником або обмеженою кількістю інтегральних показників, які відбивають якісну оцінку стану СВК.

Однак, застосування єдиного інтегрального показника уявляється малоймовірним у зв'язку із широким спектром різнорідних об'єктів (задач) СВК та тим, що деякі об'єкти СВК можуть бути оцінені лише вербально-якісними оцінками, а для деяких - можливо і доцільно застосування кількісних оцінок.

При розробці (адаптації) методики оцінювання ефективності СВК, в даному дослідженні запропонована комбінація 
системного підходу та підходу, який базується на теорії організаційного управління. Загальна ефективність організації, як інтегральний показник залежить від ефективного виконання нею функцій, за умови високого рівня продуктивності. Вибір критеріїв ефективності залежить від конкретних умов функціонування організації. Спираючись системний підхід, організація виступає елементом більш масштабної системи, отримуючи ресурси, обробляє їх та повертає у видозміненому стані (готовий продукт). Ефективність даного процесу (затрати процес - випуск) напряму пов'язані із виживанням організації, тобто адаптацією до зовнішнього середовища. Головним інтегральним критерієм ефективності організації $€$ їі виживання в довгостроковій перспективі, однак необхідні критерії нижчого рівня, які будуть його оцінювати та відображати взаємозв'язок із фактором часу. Даний зв'язок зображено на рис.3.

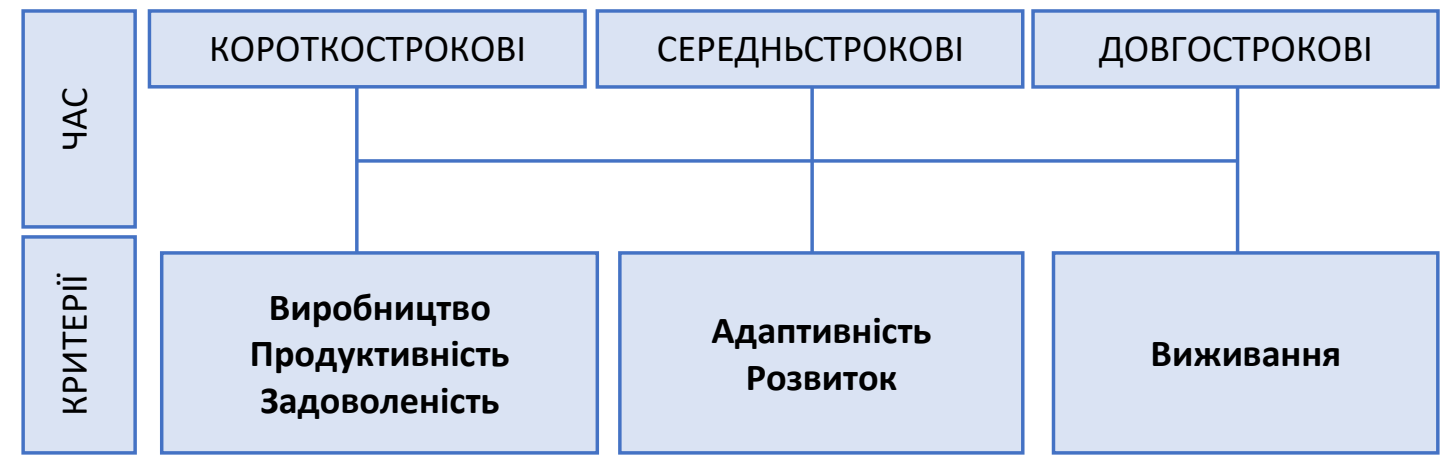

Рисунок 3 - Взаємозв'язки між фактором часу і критеріями ефективності [20]

Адаптуємо даний підхід до визначення критеріїв, представлений на Рис.3, для потреб Міністерства оборони України та Збройних Сил України як єдиної системи (елементу забезпечення життєздатності держави в цілому) забезпечення воєнної безпеки держави (далі-організація).

Виробництво: відображає здатність Міністерства оборони та Збройних Сил України надавати державі та суспільству в цілому послуги із забезпечення воєнної безпеки. Даний критерій $€$ інтегральним і може оцінюватись показниками:

спроможності - відповідно до підходів у оборонному плануванні на основі спроможностей, відображає визначений норматив (здатність), який має бути досягнутий у майбутньому;

здатності - наявні спроможності на конкретний момент часу;

можливості - наявні ресурси (матеріальні і нематеріальні, економічні, політичні, технологічні, інші), та/або потенційні, які піддаються плануванню та прогнозуванню, що забезпечують на належному рівні здатності і дають можливість планувати досягнення запланованого рівня спроможностей.

Продуктивність: визначається як співвідношення продукту до обсягів ресурсів, які вводяться в систему, тобто закладені нормативи воєнної безпеки досягаються за рахунок необхідного мінімального обсягу передбачених для цього ресурсів (напряму залежать від показника можливості).

Задоволеність: даний критерій відображає рівень задоволеності зовнішніх та внутрішніх користувачів системи.

Внутрішніми користувачами виступають військовослужбовці та цивільні представники Міністерства оборони України та Збройних Сил України. В даному аспекті можна розглянути критерій - рівень вмотивованості, який залежить від різних показників, які можливо розглядати через мотиваційну теорію Маслоу. Але рівень грошового забезпечення, “соціальний пакет” (нижній 
рівень потреб за теорією Маслоу) на сьогодні в Україні стоїть гостро. Також важливим показником задоволеності $€$ престиж професії (конкурс на одне місце, співвідношення грошового забезпечення до середньої заробітної плати в державі).

Зовнішніми користувачами виступає держава в особі суспільства, яке зацікавлено В збереженні сталого соціальноекономічного розвитку за відсутності зовнішніх загроз, що $€$ одним із важливих показників інвестиційної привабливості держави. Ефективність за даним критерієм можна оцінити за показниками рівня виконання завдань покладених на Міністерство оборони та Збройні Сили України.

Адаптивність: відображає рівень здатності організації адекватно реагувати на зміни внутрішнього середовища. Низький рівень адаптивності сигналізує про низьку ступінь керованості (менеджменту), потребує внесення змін задля збереження свого існування, подолання загроз. Для Міністерства оборони України та Збройних Сил України полягає в здатності адаптуватись до загроз національній безпеці у співвідношенні до рівня виділених необхідних для цього ресурсів; змін у внутрішній політиці держави по відношенню до Міністерства оборони України та Збройних Сил України.

Розвиток: ціль полягає в постійному нарощуванні здатності організації виживати в довгостроковій перспективі. Розвиток та виживання організації $€$ критеріями, які завершують згортання попередніх рівнів критеріїв та по суті формують остаточний інтегральний критерій - загальну ефективність системи (організації). Для Міністерства оборони України та Збройних Сил України це означає досягнення визначених спроможностей у програмах розвитку та актуальності цих спроможностей до вимог часу, коли вони були досягнуті.

Показниками можуть виступати здатність забезпечити необхідний рівень військової безпеки в державі спираючись на наявні здатності організації.
Перші три показники конкретніше і чіткіше, ніж показники адаптивності і розвитку, тому об'єктивність визначення відносної організаційної ефективності доцільніше проводити використовуючи короткострокові, а не середньо- та довгострокові критерії.

Адаптація визначених критеріїв до системи COSO можлива в розрізі елементів (“куб COSO"), як при оцінці ефективності проектування СВК так і при оцінці ефективності її операційного застосування на рівні організації в цілому.

Запропонований підхід (рис. 3) до визначення критеріїв ефективності організації застосуємо для оцінювання ефективності СВК.

Виробництво: при аналізі нормативноправової бази було визначено основний результат (продукт) діяльності ПВА створення додаткової цінності (тобто приносити користь) організації, яка полягає у наданні відповідних рекомендацій: щодо системи управління, процесів управління ризиками, СВК. Результатом функціонування CВK є: досягнення мети діяльності організації, управління ризиками реальними i потенційними, забезпечення достатніх гарантій у досягненні мети організації.

$$
\text { Достатні гарантії визначаються }
$$
відповідним рівнем впевненості при існуючих витратах, вигодах та ризиках. Можна зобразити формулою:

$$
\begin{aligned}
& \mathrm{K}_{\mathrm{B}}= \mathrm{B}_{\text {д }}-\mathrm{B}_{\mathrm{T}}-\mathrm{B}_{\text {тп }} \\
& \mathrm{K}_{\mathrm{B}}>0 \rightarrow \max
\end{aligned}
$$

$\mathrm{K}_{\mathrm{B}}$ - показник рівня впевненості;

$\mathrm{B}_{\text {д }}$ - вигоди;

$\mathrm{B}_{\mathrm{T}}$ - витрати;

$\mathrm{B}_{\text {тп }}$ - потенційні витрати (ризики втрат).

Даний критерій підкріплюється відповідними показниками: спроможностей, можливостей та здатностей, розглянутих вище.

Продуктивність: визначається як співвідношення продукту до обсягів ресурсів, які вводяться в систему:

досягнення цільових нормативів спроможностей організації; 
досягнення допустимого інтегрального показника рівня всіх реальних і потенційних ризиків, які відповідають нормативу “ризикапетиту" для організації при постійному зниженні рівня їх впливу (матеріальних і нематеріальних втрат);

досягнення достатнього рівня гарантій для керівництва організації при досягненні мети ії функціонування.

Ці процеси досягаються за рахунок необхідного мінімального обсягу передбачених для цього ресурсів (напряму залежать від показника можливості).

$$
\text { Продуктивність }=\frac{\text { Спроможності }}{\text { Можливості }}
$$

Задоволеність: відображає рівень задоволеності керівництва організації на шляху до досягнення цілей організації, та зниження впливу ризиків, шляхом ефективного управління ними. Наприклад, рівень досягнення планових показників організації, співвідношення ідентифікованих та скерованих ризиків до фактичних негативних подій, що стались, рівень довіри: відсоток прийнятих до виконання рекомендацій внутрішніх аудиторів.

Адаптивність: даний критерій по відношенню до СВК, має відображати здатність своєчасної адаптації СВК до змін у внутрішньому та зовнішньому середовищі. Здатність актуалізувати нові та старі ризики до конкретного моменту в часі. Адаптувати стратегію розвитку організації до існуючих умов із збереженням нормативних показників спроможностей організації. Показниками можуть виступати: рівень збитків та втрат (матеріальних і нематеріальних (репутаційних)), пов'язаних із несвоєчасним або помилковим прийняттям рішень.

Розвиток: здатність СВК накопичувати власний досвід, адаптуючи його до нових умов, адаптувати запозичений досвід, здатність до безперервного навчання задіяних осіб та спрямування нових знань в розвиток СВК, зростання ролі ПВА при прийнятті важливих рішень в організації. Даний критерій СВК тісно пов'язаний із розвитком системи внутрішнього аудиту та ії роллю, яку відіграє ПВА як дорадчий орган. Тобто, якщо при прийнятті важливих рішень думка ПВА має вплив на їх успішну реалізацію, то СВК функціонує ефективно і розвивається відповідно до потреб організації та можна використати, як показник критерію “Розвиток”.

Важливим фактором, який впливає на рівень ефективності СВК є людський фактор (людських помилок та зловживань). Тому рівень автоматизації процесів в організації може суттєво знизити зазначені ризики та вплинути на ефективність СВК.

\section{Висновки}

В Україні назріла необхідність в об'єктивному оцінюванні ефективності СВК, яка функціонує тривалий час в державному секторі. Але системного підходу до оцінювання СВК у вигляді затвердженої методики не існує, що ускладнює внутрішній аудит ефективності СВК на рівні державних установ. Тому, на сьогодення, дана задача фактично лежить на самих організаціях.

Аналіз існуючих стандартів (керівництв) СВК та управління ризиками, які діють провідних країнах світу, проведений в статті з використанням відповідних критеріїв показав, що для державного сектору України найбільш доцільним $€$ стандарт COSO, як такій, що краще відповідає вимогам в оцінюванні їі ефективності зі сторони ПВА.

Використовуючи модель

COSO запропоновано адаптувати підходи теорії організації і теорії систем для визначення ключових критеріїв та показників ефективності діяльності організації та ефективності функціонування СВК в організації, виходячи із припущення, що СВК, можна розглядати, як відповідну систему у довгостроковому періоді. Роль системи внутрішнього аудиту $\epsilon$ визначальною, не тільки при оцінюванні ефективності СВК, але і у підвищенні рівня ії ефективності через розвиток ПВА та підвищення рівня довіри до 
нього зі сторони керівництва організації.

Підсумовуючи, можна стверджувати, що система внутрішнього аудиту має виступати механізмом розвитку та підвищення рівня ефективності СВК. Визначення критеріїв і показників ефективності СВК є складною і багатогранною проблемою, яку слід вирішувати через призму встановлення залежності ефективності виконання функцій покладених на організацію, як результату впливу СВК.

\section{Список використаних джерел}

1. Бюджетний кодекс України від 8 липня 2010 року № 2456-VI

2. Основні засади здійснення внутрішнього контролю розпорядниками бюджетних коштів: Постанова Кабінету Міністрів України від 12 грудня 2018 року №1062

3. Деякі питання здійснення внутрішнього аудиту та утворення підрозділів внутрішнього аудиту: Постанова Кабінету Міністрів України від 28 вересня 2011 р. №1001

4. Про організацію діяльності з внутрішнього аудиту в системі Міністерства оборони України: Наказ Міністерства оборони України №475 від 15.12.2020

5. Про затвердження Положення про Департамент внутрішнього аудиту Міністерства оборони України: Наказ Міністерства оборони України від 5 червня 2019 року № 280

6. Про затвердження Порядку організації системі Міністерства оборони України внутрішнього контролю та управління ризиками: Наказ Міністерства оборони України від 4 квітня 2019 року № 145

7. Проект методичного посібника "Внутрішній аудит ефективності: методичні засади та практичні аспекти" URL: https://www.mof.gov.ua/storage/files/ project_vn_audit_efect.pdf (дата звернення: 25.05.2021)

8. Про затвердження Стандартів внутрішнього аудиту: Наказ Міністерства фінансів України від 04.10.2011 № 1247

9. Enterprise Risk Management-Integrating with Strategy and Performance (2017) URL: https://www.coso.org/Pages/erm.aspx. (дата звернення: 25.05.2021)

10. A Guide To The Sarbanes-Oxley Act. URL: https://www.soxlaw.com. (дата звернення: 25.05.2021)
11. FERMA a risk management standard. Federation of European risk management association URL: https://www.ferma.eu/app/uploads/2011/11 /a-risk-management-standard-russianversion.pdf (дата звернення: 25.05.2021)

12. ISO 31000:2018 Risk management Guidelines. $2018 . \quad$ URL: https://www.iso.org/ru/standard/65694.html (дата звернення: 25.05.2021)

13. Стрельник М. М. Сравнение стандартов управления рисками (COSO ERM, FERMA и ISO 31000:2009) // Известия СПбГЭУ. 2014. №5 (89). URL: https://cyberleninka.ru/article/n/sravneniestandartov-upravleniya-riskami-coso-ermferma-i-iso-31000-2009 (дата звернення: 25.05.2021)

14. ISO 9004: 2009 Журнал “Менеджмент". Стандарти ISO. URL: https://isomanagement.com/wpcontent/uploads/2017/07/ISO-9004-2009.pdf (дата звернення: 25.05.2021)

15. ISO/DIS 9001: 2014 Журнал “Менеджмент”. Стандарти ISO. URL: https://isomanagement.com/wp-content/ uploads/2014/08/ISO-9001_2015.pdf (дата звернення: 25.05.2021)

16. Каменська Т. О. Внутрішній аудит: методологія та організація: автореферат дисертації доктора економічних наук: 08.00.09 / Т.О. Каменська; Нац. акад. статистики, обліку та аудиту. - K., 2011. URL: http://194.44.12.92:8080/jspui/bitstream/123 456789/706/1/\%D0\%9A\%D0\%B0\%D0\%BC\%D 0\%B5\%D0\%BD\%D1\%81\%D1\%8C\%D0\%BA\%D0 \%B0.PDF (дата звернення: 25.05.2021)

17. Стандарти внутрішнього контролю в Міністерстві оборони та Збройних Силах України. URL: https://www.mil.gov.ua/ content/pdf/vnytr_con 
trol/Internal\%20Control\%20Standards_ukr.pd

$f$ (дата звернення: 25.05.2021)

18. The Institute of Internal Auditors Research Foundation. Evaluating Internal Control Systems https://www.interniaudit.cz/download /IIA/Evaluating-Internal-Control-Systems.pdf (дата звернення: 25.05.2021)

19. The International Federation of Accountants (IFAC). Evaluating and Improving Internal Control in Organizations. URL: https://www.ifac.org/about-ifac/professionalaccountants-business/

publications/evaluating-and-improvinginternal-control-organizations-0 (дата звернення: 25.05.2021)

20. Теория организации: учебное пособие / Л. С. Ружанская, А. А. Яшин, Ю. В. Солдатова; под общ. ред. Л. С. Ружанской. Екатеринбург : изд-во Урал. ун-та, 2015. $200 \mathrm{c}$.

21. HB158: Delivering Assurance Based on ISO 31000:2009 Risk Management-Principles and Guidelines (Standards Australia, Standards New Zealand, and the Institute of Internal Auditors-Australia, 2010). Evaluating and Improving Internal Control in Organizations. URL: https://infostore.saiglobal.com/enau/standards/hb-158-2010-

129591_saig_as_as_274229 (дата звернення: 25.05.2021)

22. The King Code of Governance for South Africa (King III) came into effect. URL: https://www.iodsa.co.za/page/King3 (дата звернення: 25.05.2021)

23. IDW Accounting Standard IDW RS FAIT 1 Grundsätze ordnungsmäßiger Buchführung bei Einsatz von Informationstechnologie (Principles of Proper Booking When Applying Information Technology (Institut der Wirtschaftsprüfer, 2002). URL: https://www. idw.de/idw/verlautbarungen/idw-rs-fait-

1/42928 (дата звернення: 25.05.2021)

24. Rules for Risk Management: Culture, Behaviour and the Role of Accountants (Association of Chartered Certified Accountants, 2012). URL:https://www.bryanwhitefield.com.au/wp content/uploads/stories/Whitepapers/ACCA_ Risk_5-mins.pdf (дата звернення: 25.05.2021)

25. Internal Control: Guidance to Directors (UK Financial Reporting Council, 2005), URL: https://www.frc.org.uk/getattachment/fe1ba 51a-578d-4467-a00c-f287825aced9/RevisedTurnbull-Guidance-October-2005.pdf (дата звернення: 25.05.2021)

26. COBIT, developed and issued by ISACA. URL: https://www.academia.edu/24174878/A_Busi ness_Framework_for_the_Governance_and Management_of_Enterprise_IT_PREVIEW_VE RSION (дата звернення: 25.05.2021)

27. Framework for Board Oversight of Risk (Canadian Institute of Chartered Accountants, 2012). URL: https://www.cpacanada.ca//media/site/operational/rg-researchguidance-and-support/docs/02481-rgframework-board-oversight-enterprise-riskmay-2020.pdf? (дата звернення: 25.05.2021).

\section{Концептуальные подходы к формированию критериев оценки эффективности системы внутреннего контроля в Министерстве обороны Украины}

\footnotetext{
Станислав Слободяник * 1 А; Павел Пархоменко 2 А; Олександр Деменев ${ }^{3}$; Иван Ткач ${ }^{3 \text { A }}$

* Corresponding author: ${ }^{1}$ к.э.н., с.н.с., ведущий научный сотрудник научно-исследовательской лаборатории проблем финансового обеспечения, e-mail: 8s.8@ukr.net, ORCID: 0000-0001-5537-2723

2 к.э.н., старший преподаватель кафедры, e-mail: p_parhomenko@ukr.net, ORCID: 0000-0002-1026-3723

3 к.т.н., доцент, доцент кафедры, e-mail: p_parhomenko@ukr.net

${ }^{4}$ Доктор экономических наук, профессор, начальник центра оборонного менеджмента, e-mail: tkachivan9@gmail.com, ORCID: 0000-0001-5547-6303

А Национальный университет обороны Украины имени Ивана Черняховского, пр-кт Воздухофлотский, 28, г. Киев, 03049, Украина
} 


\begin{abstract}
Аннотация
В статье рассматриваются основные причины замедления развития системы внутреннего контроля в государственном секторе Украины, которая выступает инструментом повышения эффективности функционирования объекта контроля в целом. Целью статьи является разработка на базе системного и процессного подходов, концептуальных подходов к формированию критериев оценки эффективности системы внутреннего контроля в долгосрочной перспективе и определение наиболее адаптированного стандарта для данной цели. В процессе достижения цели исследования использовались следующие методы: анализ, синтез, индукция, дедукция, системный подход, аналогия.

Мировая тенденция к повышению прозрачности функционирования государственных учреждений реализуется путем внедрения системы внутреннего контроля, как элемента системы управления организацией. При этом возникает необходимость в оценке эффективности самой системы.

Функционирование надлежащего внутреннего контроля и внутреннего аудита является обязательным условием вступления новых членов в ЕС. Проведенный анализ отечественной нормативно-правовой базы в сфере функционирования системы внутреннего контроля показал отсутствие в Украине единой методики оценки ее эффективности в государственном секторе и необходимость ее создания.
\end{abstract}

Ключевые слова: внутренний контроль, внутренний аудит, эффективность, COSO, FERMA.

\title{
Conceptual approaches to the formation of criteria for evaluating the effectiveness of the internal control system in the ministry of defense of Ukraine
}

\author{
Stanislav Slobodianyk ${ }^{1 \text { A; }}$ Pavlo Parkhomenko ${ }^{2}$; \\ Oleksandr Demenev ${ }^{3}$; ; Ivan Tkach ${ }^{3 \text { B }}$ \\ * Corresponding author: ${ }^{1}$ Ph.D., Senior Researcher Fellow, a leading researcher in the research laboratory of financial support issues, e-mail: \\ 8s.8@ukr.net, ORCID: 0000-0001-5537-2723 \\ 2 Ph.D., Senior Lecturer of the Department of Economics and Financial Support, e-mail: p_parhomenko@ukr.net, ORCID: 0000-0002-1026-3723 \\ ${ }^{3}$ Ph.D., associate professor, associate professor of the department, e-mail: p_parhomenko@ukr.net \\ ${ }^{4}$ Doctor of Economics, Professor, Head of the Center, e-mail: tkachivan9@gmail.com, ORCID: 0000-0001-5547-6303 \\ A National Defence University of Ukraine named Ivan Chernyakhovsky, 28, Povitroflotsky Ave., Kyiv, 03049, Ukraine
}

\begin{abstract}
The article deals with the main reasons for the slowdown in the development of the internal control system in the public sector of Ukraine. It acts as an instrument for increasing the efficiency of the control object in general. The purpose of the article is to develop conceptual approaches, based on systemic and process approaches, to the formation of criteria for assessing the efficiency of the internal control system in the long run and the determination of the most adapted standard for this purpose. In the course of achieving the research goal, the following methods were used: analysis, synthesis, induction, deduction, systematic approach, analogy.

The global tendency to increase the transparency of the functioning of state institutions is realized by implementation an internal control system as an element of the institution management system. In this case, there is a need to evaluate the efficiency of this system.

The functioning of appropriate internal control and internal audit is a prerequisite for the accession of new members in the EU. The analysis of the domestic regulatory framework in the field of functioning of the internal control system showed the absence of an only methodology for evaluating its efficiency in the public sector and an urgent need for its creation in Ukraine.
\end{abstract}

Keywords: internal control, internal audit, efficiency, COSO, FERMA. 


\section{References}

1. Byudzhetny kodeks Ukrainy vid 8 lipnya 2010 roku № 2456-VI

2. Postanova Kabinetu Ministriv Ukrainy vid 12 grudnya 2018 roku №1062 “Osnovni zasady zdiysnennya vnutrishn'ogo kontrolyu rozporyadnykamy byudzhetnikh koshtiv"

3. Postanova Kabinetu Ministriv Ukrainy vid 28 veresnya 2011 r. № 1001 "Deyaki pytannya zdiysnennya vnutrishn'ogo auditu ta utvorennya pidrozdiliv vnutrishn'ogo auditu"

4. Nakaz Ministerstva oboroni Ukrainy №475 vid 15.12.2020 "Pro organizatsiyu diyal'nosti z vnutrishn'ogo auditu $v$ sistemi Ministerstva oborony Ukrainy"

5. Nakaz Ministerstva oboroni Ukrainy vid 5 chervnya 2019 roku № 280 "Pro zatverdzhennya Polozhennya pro Departament vnutrishn'ogo auditu Ministerstva oboroni Ukrainy"

6. Nakaz Ministerstva oboroni Ukrainy vid 4 kvitnya 2019 roku № 145 “Pro zatverdzhennya Poryadku organizatsii sistemy Ministerstva oboroni Ukrainy vnutrishn'ogo kontrolyu ta upravlinnya ryzykamy"

7. Proekt metodichnogo posibnika "Vnutrishniy audit efektivnosti: metodichni zasady ta praktichni aspekty" Available from: https://www.

mof.gov.ua/storage/files/project_vn_audit_ef ect.pdf (data zvernennya: 25.05.2021)

8. Nakaz Ministerstva finansiv Ukrainy vid 04.10.2011 № 1247 "Pro zatverdzhennya Standartiv vnutrishn'ogo auditu"

9. Enterprise Risk Management-Integrating with Strategy and Performance (2017) Available from: https://www.coso.org/Pages/erm.aspx. (data zvernennya: 25.05.2021)

10. A Guide To The Sarbanes-Oxley Act. Available from: https://www.soxlaw.com. (data zvernennya: 25.05.2021)

11. FERMA a risk management standard. Federation of European risk management association Available from: https://www.ferma.eu/app/uploads/2011/11 /a-risk-management-standard-russianversion.pdf (data zvernennya: 25.05.2021)

12. ISO 31000:2018 Risk management -
Guidelines. 2018. Available from: https://www.iso.org/ru/standard/65694.html (data zvernennya: 25.05.2021)

13. Strel'nik Mikhail Mikhailovich. Sravnenie standartov upravleniya riskami (COSO ERM, FERMA i ISO 31000:2009) // Izvestiya SPBGEHU. 2014. №5 (89). Available from: https://cyberleninka.ru/article/n/sravneniestandartov-upravleniya-riskami-coso-ermferma-i-iso-31000-2009 (data zvernennya: 25.05.2021)

14. ISO 9004: 2009 Zhurnal "Menedzhment". Standarty ISO. Available from: https://isomanagement.com/wpcontent/uploads/2017/07/ISO-9004-2009.pdf (data zvernennya: 25.05.2021)

15. ISO/DIS 9001: 2014 Zhurnal "Menedzhment". Standarty ISO. Available from: https://isomanagement.com/wpcontent/uploads/2014/08/ISO-9001_2015.pdf (data zvernennya: 25.05.2021)

16. Kamens'ka T.O. Vnutrishniy audit: metodologiya ta organizatsiya: avtoreferat disertatsii doktora ekonomichnikh nauk: 08.00.09 / T.O. Kamens'ka; Nats. akad. statistiki, obliku ta auditu. - Kyiv, 2011. Available from: http://194.44.12.92:8080/jspui/bitstream/123 456789/706/1/\%D0\%9A\%D0\%B0\%D0\%BC\%D 0\%B5\%D0\%BD\%D1\%81\%D1\%8C\%D0\%BA\%D0 \%BO.PDF (data zvernennya: 25.05.2021).

17. Standarti vnutrishn'ogo kontrolyu v Ministerstvi oborony ta Zbroinikh Silakh Ukrainy. Available from: https://www.mil.gov.ua/content/pdf/vnytr_c on

trol/Internal\%20Control\%20Standards_ukr.pd $\mathrm{f}$ (data zvernennya: 25.05 .2021 )

18. The Institute of Internal Auditors Research Foundation. Evaluating Internal Control Systems Available from: https://www.interniaudit.cz/download /IIA/Evaluating-Internal-Control-Systems.pdf (data zvernennya: 25.05.2021)

19. The International Federation of Accountants (IFAC). Evaluating and Improving Internal Control in Organizations. Available from: 
https://www.ifac.org/about-ifac/professionalaccountants-business/

publications/evaluating-and-improvinginternal-control-organizations-0 (data zvernennya: 25.05.2021)

20. Teoriya organizatsii: uchebnoe posobie / L.S. Ruzhanskaya, A.A. Yashin, YU. V. Soldatova; pod obshch. red. L. S. Ruzhanskoi. Ekaterinburg : izd-vo Ural. unta, 2015. - $200 \mathrm{~s}$.

21. HB158: Delivering Assurance Based on ISO 31000:2009 Risk Management-Principles and Guidelines (Standards Australia, Standards New Zealand, and the Institute of Internal Auditors-Australia, 2010). Evaluating and Improving Internal Control in Organizations. Available from:

https://infostore.saiglobal.com/enau/standards/hb-158-2010-

$$
\text { 129591_saig_as_as__ } 274229 \quad \text { (data }
$$
zvernennya: 25.05.2021)

22. The King Code of Governance for South Africa (King III) came into effect. Available from: https://www.iodsa.co.za/page/King3 (data zvernennya: 25.05.2021)

23. IDW Accounting Standard IDW RS FAIT 1 Grundsätze ordnungsmäßiger Buchführung bei Einsatz von Informationstechnologie (Principles of Proper Booking When Applying Information Technology (Institut der Wirtschaftsprüfer, 2002). URL: https://www. idw.de/idw/verlautbarungen/idw-rs-fait1/42928 (data zvernennya: 25.05.2021)

24. Rules for Risk Management: Culture, Behaviour and the Role of Accountants (Association of Chartered Certified Accountants, 2012). Available from: https://www.bryanwhitefield.com.au/wpcont ent/uploads/stories/Whitepapers/ACCA_Risk_ 5-mins.pdf (data zvernennya: 25.05.2021)

25. Internal Control: Guidance to Directors (UK Financial Reporting Council, 2005), Available from:

https://www.frc.org.uk/getattachment/fe1ba 51a-578d-4467-a00c-f287825aced9/RevisedTurnbull-Guidance-October-2005.pdf (data zvernennya: 25.05.2021)

26. COBIT, developed and issued by ISACA. Available from: https://www.academia.edu/24174878/A_Busi ness_Framework_for_the_Governance_and_ Management_of_Enterprise_IT_PREVIEW_VE RSION (data zvernennya: 25.05.2021)

27. Framework for Board Oversight of Risk (Canadian Institute of Chartered Accountants, 2012). Available from: https://www.cpacanada.ca//media/site/operational/rg-researchguidance-and-support/docs/02481-rgframework-board-oversight-enterprise-riskmay-2020.pdf? (data zvernennya: 25.05.2021). 